\title{
Evaluation of the stability and antimicrobial activity of an ethanolic extract of Libidibia ferrea
}

This article was published in the following Dove Press journal:

Clinical, Cosmetic and Investigational Dentistry

28 January 2014

Number of times this article has been viewed

\section{Raquel de Oliveira \\ Marreiro' \\ Maria Fulgência Costa Lima \\ Bandeira' \\ Tatiane Pereira de Souza ${ }^{2}$ \\ Mailza Costa de Almeida' \\ Katiana Bendaham' \\ Gisely Naura Venâncio' \\ Isis Costa Rodrigues ${ }^{2}$ \\ Cristiane Nagai Coelho' \\ Patrícia Sâmea Lêdo Lima \\ Milério' \\ Glauber Palma de Oliveira' \\ Nikeila Chacon de Oliveira \\ Conde'}

'School of Dentistry, Federal

University of Amazonas, Manaus,

Amazonas; ${ }^{2}$ School of Pharmacy,

Federal University of Amazonas,

Manaus, Amazonas, Brazil
Correspondence: Gisely Naura Venâncio School of Dentistry, Federal University of Amazonas, Waldemar Pedrosa Avenue, I539, Downtown, 69025-050,

Manaus, Amazonas, Brazil

Tel +92 88390595

Email ginaura@gmail.com
Abstract: Biofilm is a dense, whitish, noncalcified aggregate of bacteria, with desquamated epithelial cells and food debris creating conditions for an imbalance of resident oral microflora and favoring the destruction of hard and soft tissues by development of caries and gingivitis. The aim of this study was to obtain and characterize an extract of Libidibia ferrea, ex Caesalpinia ferrea L. and to evaluate its feasibility for formulation as a mouthwash, according to current legislation. For this purpose, $\mathrm{pH}$, sedimentation, density, and stability were evaluated, along with microbiological testing of the extract. The microbiological test was used to verify the presence of Staphylococcus aureus, Pseudomonas aeruginosa, fungi, yeasts, coliforms, and minimum inhibitory concentrations of Streptococcus mutans and Streptococcus oralis strains. Characterization, microbiological evaluation, and minimum inhibitory concentration results were tabulated and described using descriptive statistics. The L. ferrea extract showed stable characteristics, product quality, and antibacterial activity against the microorganisms tested irrespective of experimental time intervals. According to these results, it can be concluded that formulation of a mouthwash containing $L$. ferrea extract to control biofilm is feasible, but further studies are needed.

Keywords: biofilm, extract, quality control

\section{Introduction}

Dental plaque is defined as a community of oral bacteria on a tooth surface in which microorganisms are found embedded in the extracellular polymeric substance and in intimate communication with each other via several different pathways, such as auto/ coaggregation, metabolic communication, quorum sensing, and competent stimulation peptides. ${ }^{1}$

Dental caries and periodontal disease are initiated by accumulation of plaque on the soft tissue and on the tooth surface, leading to tooth loss and gum problems. ${ }^{2}$ A consequence of such biofilm growth is increased resistance to chemical antimicrobial agents and antibiotics, ${ }^{3,4}$ which has profound implications in the oral environment and in medicine.

Biofilm can be controlled by mechanical procedures or by chemical intervention. Mechanical control is the most effective method, but is not always done properly. Thus, antimicrobial substances have been used for chemical control of dental biofilm, working as aids to mechanical procedures and for specific conditions..$^{5-7}$ Given the incidence of oral disease, increased bacterial resistance to antibiotics, the adverse affects of some antibacterial agents currently used in dentistry, and financial considerations in developing countries, there is a need for alternative prevention and treatment options 
that are safe, effective, and economical. Hence, the search for alternative products continues, and natural phytochemicals isolated from plants used as traditional medicines are considered good alternatives. ${ }^{8}$ The search for therapeutic applications of medicinal plants and their derivatives has been growing in recent years throughout the world. Several studies have been carried out in order to evaluate new therapeutic use of plants. The discovery of new antimicrobial components is relevant, given that bacterial and fungal infections of the oral cavity are a relatively common problem. For example, Candida albicans is opportunistic yeast commonly identified in denture stomatitis and other forms of oral candidosis, and Streptococcus mutans is associated with dental biofilm and one of the most important microorganisms involved in dental caries. ${ }^{9}$

Studies have been conducted to assess the activity of plants of the Amazon flora against the microorganisms present in dental biofilm. ${ }^{10-12}$ The significant global growth of phytotherapy as part of preventive and curative programs has encouraged assessment of the activity of a number of plant extracts. The ancient practice of members of a community using plants to re-establish health, common to all people but almost forgotten for decades, has become increasingly more intense in the civilized world in recent years. ${ }^{13}$ In the Amazon region of Brazil, the fruit of Libidibia ferrea is widely used as an antimicrobial and healing medicine in many situations, including oral infections. ${ }^{14}$ Based on these observations, the aim of this study was to evaluate the antibacterial activity of $L$. ferrea extract against microorganisms present in biofilm, in the hope of making it a future complementary method for chemical control of biofilm formation.

\section{Materials and methods}

The dry fruit of L. ferrea (228022-INPA), a species of the family Leguminosae caesalpiniaceae, known as jucá, jucaína, and pau-ferro (Brazilian ironwood), was collected at the National Institute of Amazon Research and processed at the School of Pharmaceutical Sciences, Federal University of Amazonas. The alcoholic extract was prepared by maceration at room temperature for 72 hours using ethanol as the solvent and $10 \%(\mathrm{w} / \mathrm{v})$ of raw vegetable material. After extraction, the extract was filtered and taken to the vacuum evaporator (RV10 basic rotary evaporator, IKA ${ }^{\circledR}$-Werke $\mathrm{GmbH}$ and Co, Staufen, Germany) to remove the solvent. The residue was then stored in previously sterilized and dried amber bottles with lids.

\section{Characterization of hydroalcoholic} extract

Characterization of the extract was performed using three different storage environments, ie, an oven $\left(37^{\circ} \mathrm{C}\right)$, room temperature $\left(24^{\circ} \mathrm{C}-26^{\circ} \mathrm{C}\right)$, and a refrigerator $\left( \pm 4.8^{\circ} \mathrm{C}\right)$ at experimental time intervals of $0,7,30,45$, and 90 days.

Aliquots of the extract were withdrawn aseptically with the aid of an automatic pipette and the following were assessed: $\mathrm{pH}$, using a pH meter (pHtek, PHS-3B ${ }^{\circledR}$, Campinas, São Paulo, Brazil); sedimentation, by rotational speed in a centrifuge at 1,500 and 3,000 rpm for 5 minutes (Nova técnica $^{\circledR}, \mathrm{Nt810}$, Piracicaba, São Paulo, Brazil); organoleptic characteristics (color, odor, consistency, and brightness), by visual-tactile assessment; and density, using the dry pycnometer method. ${ }^{15}$

\section{Microbiological evaluation}

The extract was analyzed for the existence of microorganisms to verify the presence or absence of Staphylococcus aureus and Pseudomonas aeruginosa in Plate Count Agar, Baird-Parker, and Cetrimide media and fungi and yeasts using Sabouraud Agar. The presence or absence of growth was analyzed by counting colony-forming units. Cultivation was done in triplicate for each experimental time interval and condition.

Escherichia coli broth was used at a proportion of $10 \mathrm{~mL}$ for each tube with a lid $(15 \times 150 \mathrm{~mm})$ in inverted Durham tubes for total coliform count. For each type of culture medium used, a white group (without extract) was prepared and the whole experimental procedure was conducted in a class II biological safety cabinet.

\section{Assessment of MIC by microdilution}

The minimum inhibitory concentration (MIC) was determined using a previously reported method, ${ }^{16}$ and $100 \mu \mathrm{L}$ of liquid culture medium (Mueller-Hinton) was distributed into sterile 96-well microplates. In row A of the plate, $100 \mu \mathrm{L}$ of the extract solution was added and analyzed at a concentration of $100 \mu \mathrm{L}$ per mL. Using a 12-channel microdilution pipette, serial dilutions were made by transferring $100 \mathrm{~mL}$ from row $\mathrm{A}$ to row $\mathrm{B}$ and so on until row $\mathrm{G}$ of the plate. The last row (row $\mathrm{H}$ ) was left without any extract (test solution) and used as a control for bacterial growth. Next, $25 \mu \mathrm{L}$ of the standardized bacterial suspension and indicator solution were inoculated into each plate well. The plate was sealed and incubated at $37^{\circ} \mathrm{C}$ for 24 hours and reading was performed visually. The MIC was defined as the lowest concentration of the extract capable of inhibiting bacterial growth, ie, 
preventing color change. Five repetitions of the tests were performed. Two plates were used for the experiment against two types of bacterium ( $S$. mutans and $S$. oralis). In each plate, two groups of $L$. ferrea at different experimental time intervals were tested (extract 1 at 20 days and extract 2 at 140 days).

The results for characterization, microbiological assessment, and MIC were tabulated and submitted to descriptive analysis. For assessment of pH, the non-parametric KruskalWallis test and Epi-Info version 7 software for Windows, developed and distributed by the Centers for Disease Control and Prevention (http://www.cdc.gov/epiinfo), were used at a $5 \%$ level of significance.

\section{Results}

Characterization of the $L$. ferrea extract for $\mathrm{pH}$, density, sedimentation, and stability was performed at baseline (T0) and at 7 (T7), 30 (T30), 45 (T45), and 90 (T90) days in three storage locations, ie, a refrigerator, an oven, and at room temperature of $24^{\circ} \mathrm{C}-26^{\circ} \mathrm{C}$ (Table 1).

As shown in Table 2, the mean $\mathrm{pH}$ values in the oven were 4.32 (T0), 4.21 (T7), 4.26 (T30), 3.86 (45), and 3.42 (T90). In the refrigerator, $\mathrm{pH}$ decreased to 4.32 (T0), 4.25 (T7), 4.60 (T30), 4.30 (T45), and 3.95 (T90). At room temperature, $\mathrm{pH}$ decreased similarly to 4.32 (T0), 4.25 (T7), 4.53 (T30), 4.17 (T45), and 3.91 (T90). Analysis of variance (5\% significance level) and Tukey's test for multiple comparisons were used, and showed a statistically significant difference in $\mathrm{pH}$ in the room temperature group at $\mathrm{T} 45$ in comparison with the other groups (refrigerator and oven).

No sediment was found in the sedimentation test at $1,500 \mathrm{rpm}$. However, small amounts of sediment were found at T45 using the same test at 3,000 rpm in the oven $(1 \mathrm{~mm})$ and at room temperature $(0.2 \mathrm{~mm})$. At T90, sediment was found on storage in the refrigerator and oven $(0.5 \mathrm{~mm})$.

There was little variation in the density values, and those found for oven storage were 0.886 (T0), 0.883 (T7), 0.893 (T30), 0.889 (T45), and 0.892 (T90). In the refrigerator, the corresponding values were 0.886 (T0), 0.883 (T7), 0.893 (T30), 0.889 (T45), and 0.891 (T90). At room temperature,

Table I Mean $\mathrm{pH}$ values for the extract according to local storage conditions and trial duration

\begin{tabular}{llllll}
\hline Storage location & \multicolumn{7}{l}{ Period (days) } \\
\cline { 2 - 6 } & $\mathbf{0}$ & $\mathbf{7}$ & $\mathbf{3 0}$ & $\mathbf{4 5}$ & $\mathbf{9 0}$ \\
\hline Oven & 4.32 & 4.21 & 4.26 & 3.86 & 3.42 \\
Refrigerator & 4.32 & 4.25 & 4.60 & 4.30 & 3.95 \\
Room temperature & 4.32 & 4.25 & 4.53 & 4.17 & 3.91 \\
\hline
\end{tabular}

density was 0.886 (T0), 0.883 (T7), 0.889 (T30), 0.890 (T45), and 0.891 (T90). The differences in density between the initial and final time intervals increased by $0.006 \mathrm{~g} / \mathrm{L}$ in the oven and by $0.005 \mathrm{~g} / \mathrm{L}$ in the refrigerator and at room temperature.

The organoleptic properties of color, brightness, odor, and consistency did not change, regardless of variations in location and storage time.

No contamination of microorganisms was found in the L. ferrea extract in the microbiological tests performed to verify the presence or absence of bacteria, fungi, yeasts, and total coliforms.

Tests for antibacterial activity of the extract ( $24 \mathrm{~g}$ of L. ferrea per $100 \mathrm{~mL}$ of $80 \%$ ethanol) against S. mutans and $S$. oralis showed that extract 1 (initial time interval) had bactericidal activity in seven dilutions $(100 \mu \mathrm{L}, 50 \mu \mathrm{L}$, $25 \mu \mathrm{L}, 12.5 \mu \mathrm{L}, 6.25 \mu \mathrm{L}, 3.125 \mu \mathrm{L}$, and $1.5625 \mu \mathrm{L}$ ). At T2, the extract (final time interval, 120 days) showed bactericidal activity at a concentration of $3.125 \mu \mathrm{L}$.

\section{Discussion}

The desire for new products offering better biocompatibility and pharmacological activity with less toxicity has led to an increase in research on natural products for use in dentistry. Natural products with antimicrobial activity may be important therapeutic agents to prevent and treat caries, periodontal disease, and oral candidiasis. ${ }^{8,12,17}$

Several studies have been conducted in dentistry to evaluate plant species, including Echinacea purpurea, Copaifera multijuga, Lippia sidoides, Stryphnodendron barbatimao, and Pothomorphe umbellata. ${ }^{4,10-12,18-21}$ The present study examined the characteristics of a hydroalcoholic extract of the plant species $L$. ferrea, aiming to obtain more information for future formulation of a natural mouthwash applicable in dentistry.

The results showed no statistically significant difference in $\mathrm{pH}$ within the 45-day experimental time interval between the room temperature and refrigerator groups, but did show a significant difference in the oven group. At the end of the experiment, the $\mathrm{pH}$ of the extract was below 5.5, which is considered a critical $\mathrm{pH}$ value for dissolution of enamel, and thus must be modified in other formulations.

In the sedimentation test, at all time intervals and at different rotations, the sediments $(0.2 \mathrm{~mm}, 0.5 \mathrm{~mm}$, and $1 \mathrm{~mm}) \mathrm{did}$ not interfere with antibacterial activity. The observed variation in density was small and independent of experimental time interval or storage location.

Analyzing the different density values at the initial and final time intervals, an increase of $0.006 \mathrm{~g} / \mathrm{L}$ was found in 
Table 2 Mean of $\mathrm{pH}$ difference according to types of storage

\begin{tabular}{|c|c|c|c|c|c|c|c|c|c|c|}
\hline \multirow{3}{*}{$\begin{array}{l}\text { Period } \\
\text { (days) }\end{array}$} & \multicolumn{10}{|c|}{ Groups } \\
\hline & \multicolumn{3}{|c|}{ Room temperature $(n=3)$} & \multicolumn{3}{|c|}{ Oven $(n=3)$} & \multicolumn{3}{|c|}{ Refrigerator $(n=3)$} & \multirow[t]{2}{*}{$\mathbf{P}^{*}$} \\
\hline & Mean & $\mathbf{Q}_{1}$ & $\mathbf{Q}_{2}$ & Mean & $\mathbf{Q}_{1}$ & $\mathbf{Q}_{2}$ & Mean & $\mathbf{Q}_{1}$ & $\mathbf{Q}_{2}$ & \\
\hline $0-7$ & -0.08 & -0.21 & 0.08 & -0.11 & -0.19 & -0.02 & -0.05 & -0.21 & 0.05 & 0.967 \\
\hline $0-30$ & 0.23 & 0.07 & 0.33 & -0.07 & -0.14 & 0.04 & 0.24 & 0.23 & 0.38 & 0.055 \\
\hline $0-45$ & $-0.16^{\mathrm{a}}$ & -0.23 & -0.06 & $-0.44^{b}$ & -0.56 & -0.37 & $-0.0 \mathrm{I}^{\mathrm{a}}$ & -0.13 & 0.08 & $0.039^{\circ}$ \\
\hline $0-90$ & -0.43 & -0.49 & -0.30 & -0.89 & -0.98 & -0.81 & -0.37 & -0.45 & -0.27 & 0.061 \\
\hline
\end{tabular}

Notes: *Kruskal-Wallis test; a,b,cstatistically significant difference at a level of $5 \%$.

Abbreviations: $Q_{1}$, first quartile; $Q_{2}$, second quartile.

oven storage conditions, while in the refrigerator and at room temperature, the increase was $0.005 \mathrm{~g} / \mathrm{L}$. These variations were due to formation of substances with higher molecular weight, loss of water, or volatility of the extract; however, such modifications were not sufficient to interfere in the evaluation of the other tests.

Identification and purity of the plant, as well as evaluation of its active ingredients, are essential when trying to identify good quality products. ${ }^{11}$ In Brazil, despite wide consumption of products derived from plants, the products commercialized and consumed are not subjected to specific control.

In this study, the aim of the microbiological tests was to investigate growth of microorganisms (bacteria, fungi, yeasts, and total coliforms) in the extract. Under the conditions and types of culture medium tested, there was no indication of contamination by bacteria, fungi, yeast, or coliforms at any time interval or storage condition.

Fungal contamination of herbal drugs can lead to alteration and/or destruction of the active ingredients and loss of safety and efficacy; in addition, toxic substances (mycotoxins) may be produced, making these products unfit for consumption regardless of the level of contamination. ${ }^{22-24}$

With regard to assessment of the antibacterial activity of the $L$. ferrea extract against the $S$. mutans and $S$. oralis strains using the microdilution test on microplates to determine MIC, the tests showed that extract 1 (initial time interval) had bactericidal activity in the seven dilutions $(100 \mu \mathrm{L}$, $50 \mu \mathrm{L}, 25 \mu \mathrm{L}, 12.5 \mu \mathrm{L}, 6.25 \mu \mathrm{L}, 3.125 \mu \mathrm{L}$, and $1.5625 \mu \mathrm{L})$ established in the methodology. Extract 2 (final time interval, 120 days) showed bactericidal activity at a concentration of $3.125 \mu \mathrm{L}$. The results establish the antibacterial efficacy of the extract against the microorganisms tested after 4 months of storage. A previous study of the antimicrobial activity of L. ferrea against pathogens of the oral cavity is consistent with the present results. ${ }^{14}$

Different studies assessing the antimicrobial activity of natural products against various bacterial strains have shown positive results for such substances with regard to inhibition of growth or development of bacteria, and this has also been shown in dentistry, suggesting that plant extracts could be an alternative therapeutic option for infections of the oral cavity, such as denture stomatitis, dental caries, and periodontitis..$^{8,17,25}$ Based on the results, it is concluded that the $L$. ferrea extract has antibacterial activity against the microorganisms tested and satisfactory stability and quality, enabling the formulation of a mouthwash using this extract to control dental biofilm.

\section{Acknowledgment}

This study was supported by the Foundation for Research Support of the Amazonas State (FAPEAM).

\section{Disclosure}

The authors have no conflicts of interest to report in this work.

\section{References}

1. Rickard AH, Bachrach G, Davies D. Cell-cell communication in oral microbial communities. In: Rogers AH, editor. Molecular Oral Microbiology. Norfolk, UK: Caister Academic Press; 2008.

2. Cury JA. Controle químico da placa dental [Oral health promotion]. In: ABOPREV: Kriger L, editor. Promoção de saúde bucal. 3rd ed. São Paulo, Brazil: Artes Médicas; 2003.

3. Jyothi KS, Seshagiri M. In-vitro activity of saponins of Bauhinia purpurea, Madhuca longifolia, Celastrus paniculatus and Semecarpus anacardium on selected oral pathogens. J Dent (Tehran). 2012;9:216-223.

4. Vahabi S, Fekrazad R, Ayremlou S, Taheri S, Zangeneh N. The effect of antimicrobial photodynamic therapy with radachlorin and toluidine blue on Streptococcus mutans: an in vitro study. J Dent (Tehran). 2011;8:48-54.

5. Bugno A, Buzzo AA, Nakamura CT, Pereira TC, Matos D, Pinto TJA. Avaliação da contaminação microbiana em drogas vegetais [Evaluation of microbial contamination in herbal drugs]. Rev Ciênc Farm Básica Apl. 2005;41:491-497.

6. Fejerskov O, Kidd E. Cárie dentária - a doença e seu tratamento clínico [Dental caries - the disease and clinical treatment]. 1st ed. São Paulo, Brazil: Santos; 2005.

7. Moreira ACA, Santos TAM, Carneiro MC, Porto MR. Atividade de um enxaguatório bucal com clorexidina a 0,12 por cento sobre a microbiota sacarolítica da saliva [Activity of a mouthwash with chlorhexidine $0.12 \%$ on saccharotic saliva microbiotic]. Rev Ciênc Méd Biol. 2008;7:260-272. 
8. Palombo EA. Traditional medicinal plant extracts and natural products with activity against oral bacteria: potential application in the prevention and treatment of oral diseases. Evid Based Complement Alternat Med. 2011;2011:680354.

9. Pereira EM, Gomes RT, Freire NR, Aguiar EG, Brandão Md, Santos VR. In vitro antimicrobial activity of Brazilian medicinal plant extracts against pathogenic microorganisms of interest to dentistry. Planta Med. 2011;77:401-404.

10. Bandeira MFCL, Oliveira MRB, Pizzolito AC, Benattineto C, Jorge-Neto J. Study preliminary farmacology of the Copaifera multijuga (copaiba oil). J Bras Clin Estet Odontol. 1999;3:39-41. Portuguese.

11. Marques AA, Sponchiado EC Jr, Garcia LF, Garrido AD, França SC, Lia RC. Morphological analysis of tissue reaction caused by a new endodontic paste in subcutaneous tissue of rats. $J$ Conserv Dent. 2011;14:309-313.

12. Paixão CCB. Uso de plantas medicinais em pacientes portadores de afecções bucais [Medicinal plants in oral diseases]. Odontol Clin Cient. 2002;1:1-4.

13. Veiga VF, Zunino L, Calixto JB, Patitucci ML, Pinto AC. Phytochemical and antiedematogenic studies of commercial copaiba oils available in Brazil. Phytother Res. 2001;15:476-480.

14. Sampaio FC, Pereira Mdo S, Dias CS, Costa VC, Conde NC, Buzalaf MA. In vitro antimicrobial activity of Caesalpinia ferrea Martius fruits against oral pathogens. J. Ethnopharmacol. 2009;124:289-294.

15. Farmacopéia Brasileira. National Health Surveillance Agency. 4th ed. São Paulo, Brazil: 1988.

16. Telles MAS, Mosca A. Evaluation of the use of microtitre plate technique to determine the minimum inhibitory concentration of isoniazid in Mycobacterium tuberculosis strains. Rev Inst Adolfo Lutz. 2000;59: 15-19.
17. Castilho AR, Murata RM, Pardi V. Natural products in Dentistry. Health J. 2007:11-19.

18. Couto GBL. Biocompatibility of the Lippia sidoides Cham (Verbenaceae) hidro-alcoholic essence. Rev Cons Reg Odontol Pernambuco. 2000;3:83-90. Portuguese.

19. Feres M, Figueiredo LC, Barreto IM, Coelho MH, Araújo MW, Cortelli SC. In vitro antimicrobial activity of plant extracts and propolis in saliva samples of healthy and periodontally-involved subjects. $J$ Int Acad Periodontol. 2005;7:90-96.

20. Melo Júnior EJM, Raposo MJ, Santana AEG, Lisboa Neto JA, Diniz MFA. Estudo de plantas medicinais com atividade antimicrobiana sobre microrganismos presentes na alveolite [Study of medicinal plants with antimicrobial activity against microorganisms in alveolitis]. Rev ABO Nacional. 2000;8:4-9.

21. Vendola MCC. Equinacea purpurea na odontologia [Equinacea purpurea in Dentistry]. Técs Estéts. 2004;1:3-12.

22. Correa Júnior C, Ming LC, Schefrer MC. Cultivo de plantas medicinais e aromáticas e condimentares [Cultivation of medicinal and aromatic plants and herbs]. Jaboticabal: FUNEP, 1994.

23. Matos FJA. Plantas medicinais: guia de seleção e emprego de plantas usadas em Fitoterapia no Nordeste do Brasil [Medicinal plants: guide selection and use of plants used in herbal medicine in Northeast Brazil] Fortaleza: Imprensa Universitária-UFC, 2000.

24. Sponchiado Júnior EC, Pereira JV, Pereira JO, França SC. Pothomorphe umbellata (Caapeba). Rev Fitos. 2007;3:31-37.

25. Maekawa LE, Valera MC, Oliveira LD, Carvalho CA, Camargo $\mathrm{CH}$, Jorge AO. Effect of Zingiber officinale and propolis on microorganisms and endotoxins in root canals. J Appl Oral Sci. 2013;21:25-31.
Clinical, Cosmetic and Investigational Dentistry

\section{Publish your work in this journal}

Clinical, Cosmetic and Investigational Dentistry is an international, peer-reviewed, open access, online journal focusing on the latest clinical and experimental research in dentistry with specific emphasis on cosmetic interventions. Innovative developments in dental materials, techniques and devices that improve outcomes and patient satisfaction

\section{Dovepress}

and preference will be highlighted. The manuscript management system is completely online and includes a very quick and fair peerreview system, which is all easy to use. Visit http://www.dovepress. com/testimonials.php to read real quotes from published authors. 